\title{
Time and palaeoenvironment in the Neolithisation of the Povolzhye forest-steppe
}

\author{
Aleksandr Vybornov \\ Faculty of History, Samara State Academy of Social Sciences and Humanities, Samara, RU \\ vibornov_kin@mail.ru
}

\begin{abstract}
The paper presents the Early Neolithic Elshanka culture in Povolzhye forest-steppe. Along with the presentation of pottery assemblage the radiocarbon dates are presented and analysed. The paper addresses the question of an early pottery production in the region.
\end{abstract}

IZVLEČEK - Članek predstavlja zgodnjeneolitsko kulturo Elshanka v gozdni stepi Povolzhye. Predstavljeni in analizirani so keramični zbiri in radiokarbonski datumi. Članek se ukvarja tudi z vprašanjem o zgodnji produkciji keramike v regiji.

KEY WORDS - Middle Povolzhye; Neolithisation; pottery; ${ }^{14} \mathrm{C}$ dating

\section{Introduction}

The area of the Middle Povolzhye forest-steppe includes the western part of the Orenburg, Samara, Ulyanovsk, and Penza Regions, and the eastern part of Mordovia. In the mid-1970-s, sites were discovered on the Samara River with unusual Neolithic ceramics with pointed bottoms and faint dash ornamentation, which the researchers compared to Early Neolithic pottery from Central Asia, the Eastern Caspian Sea region, and dated to the $6-5^{\text {th }}$ millennia BP (Vasiliev, Penin 1977; Vybornov, Penin 1979). This type of pottery was denoted as Elshanka, from the name of the first site examined. As a result of studies in the 1980-90s, the number of locations yielding such ceramics increased (Fig. 1). This allowed for a number of hypotheses, some of which connected the appearance of Elshanka type ceramics with the infiltration of certain population groups from south-eastern regions (Vasiliev and Vybornov 1988; Morgounova 1995). Others showed the autochthonous nature of Elshanka cultural origins (Mamonov 1999). The discovery of sites with similar material in the western part of Middle Povolzhye have led some to propose Priazovsko-Prichernomorskiy (Kotova 2002; Stavickiy 2005) and even the Balkans (Viskalin 2002) as the primary centres of Elshanka culture. The problem of the Neolithisation of the
Middle Povolzhye is topical, in so far as some specialists consider Elshanka culture as the most ancient Neolithic pottery culture in Europe (Timofeev 2002), and that it influenced the Neolithisation of other regions (Doluhanov 2003; Nikitin 2006; Gronenborn 2009). Other specialists doubt the special status of Early Neolithic ceramics of Elshanka type (Lastovskiy 2006).

One of the most controversial questions is the periodisation of the process of Neolithisation. Mamonov (2000.158) takes the ${ }^{14} \mathrm{C}$ dates of bivalve shells found in the occupation debris of Chekalino IV, Ilyiinskaya and Lebyazhinka IV sites from $c .8600$ to 7940 BP to show that Elshanka culture was autochthonous. He suggests that Elshanka pottery was formed in the Povolzhye forest-steppe because "there is no chronological possibility of a substratum or cultural centre from which the ceramic tradition could be borrowed" (Mamonov 2006a.274). The supporters of the Balkan origins of Elshanka type sites oppose such early dates. They point to the natural occurrence of shells in the layers (Viskalin 2006), and consider the Balkan-Carpathian analogies that date these sites to the $6^{\text {th }}$ and the beginning of the $5^{\text {th }}$ millennia BP (Viskalin 2009.163). 
An alternative interpretation of the Chekalino IV dates of $8990 \pm 100 \mathrm{BP}$ (Le-4871) and 8680 \pm 120 BP (Gin7085) can be suggested; they date the Mesolithic layer. On the other hand, the dates of Iliinskaya $8510 \pm 60 \mathrm{BP}$ (Le-5839) and, Lebyazhinka IV $8470 \pm 140$ BP (Gin-7088) should be corrected because of the 'reservoir' effect. However, the shell temper in the Neolithic pottery of the northern Caspian Sea region is dated to $7235 \pm$ $45 \mathrm{BP}$ (Ua 35266), and the organic matter to $6695 \pm 40 \mathrm{BP}$ (Ua 35267) (Zaytseva et al. 2009.800). The carbonate fraction of ceramics from Kairshak III is dated to $7870 \pm 100 \mathrm{BP}$ (Ki-16401), and the organic matter from these items to $7290 \pm 190 \mathrm{BP}$ (Ki-16400). The dating based on the shells from the Lebyazhinka IV and Ilyinka sites also needs to be defined more precisely. A date of $6680 \pm 80$ BP was obtained from the organic temper in pottery from the first site, and from the latter, $6940 \pm 90 \mathrm{BP}$. Thus, the beginning of the Early Neo-

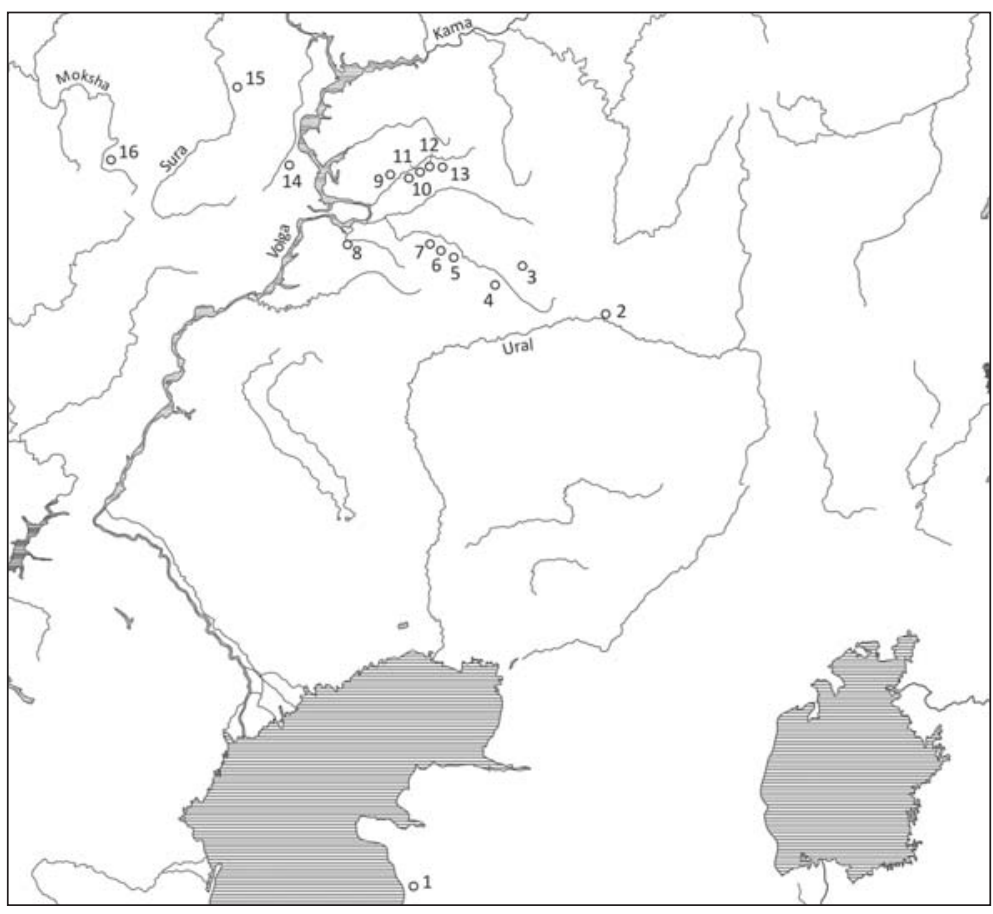

Fig. 1. Site distribution of Elshan culture in Middle Povolzhye. 1 Dzhebel. 2 Chernikov brod. 3 Ivanovskaya. 4 II Staro-Elshanskaya. 5 Vilovatovskaya. 6 Shihan. 7 Maximovka. 8 Troitskoye. 9 Ledyazhinka IV. 10 Krasniy Jar VII. 11 Iliinskaya. 12 Nizhnyaya Orlyanka II. 13 Chekalino IV. 14 Ust-Tashelka. 15 Vyunovo Lake I. 16 Ozimyenki II. lithic in the eastern part of the Middle Povolzhie forest-steppe may be dated no earlier than to the turn of the $7^{\text {th }}$ and $6^{\text {th }}$ millennia BP. The date of the bones from the layer with Elshanka ceramics at the Ivanovskaya site of $8020 \pm 90 \mathrm{BP}$ confirm this assumption. The assumption that this date can be referred to Mesolithic remains at this site is contradicted by the date $7930 \pm 90$ BP (Fig. 2), based on the organic temper in the Elshanka type pottery at the Ivanovskaya site. The correction of the lower chronological boundary of Elshanka culture from the $7^{\text {th }}$ millennium BP to the turn of the $7^{\text {th }}$ and $6^{\text {th }}$ millennia BP raises doubts as to its origin as autochthonous. At this time, not only profiled and flat bottomed ceramics appear in the region, but also the haft type arrowhead. Similar arrowheads on plates at early Hassuna sites are dated to $8065 \pm 45$ BP (MTC-04347) and 7900 \pm 120 BP (TKa-12717) (Nishiaki, Le Miere 2005.59-60). In complex XXXIII at Mersin and some other sites, they are dated to 7920 $\pm 90 \mathrm{BP}$ (Rome-467) (Balossi 2006.15, 48-49; Koztowski, Aurenche 2005.122). Researchers have thus suggested sources in Asia Minor for the Early Neolithic cultures in the steppes of European Russia and Ukraine (Danilenko 1969).

Spore/pollen tests were obtained for this chronological cycle. A sample from the lower Neolithic layer of the Ivanovskaja site shows that the region was almost bare of trees in this period. Birch was rarely found and the main areas were grassy and suffruticose, among which wormwood predominated (Morgunova 1995.174). Appropriate data were obtained directly from the bottom of the Neolithic layer. There was a prevalence of herbs, among which chenopodiacious plants and wormwood predominate. Climatic conditions were unfavourable to the growth of not only woodland, but also meadow steppe formations. Sudden changes in continental climate and a reduction in precipitation have been detected (Morgunova 1995.185), making the period comparable to the driest interval of the first part of the Atlantic period.

Thus landscape and climatic conditions of the southern part of the Volga-Urals forest-steppe at the beginning of the Atlantic period conform substantially with southern steppe and even semi-desert conditions.

Palynological data were also obtained in areas further north in the basin of the River Sok, which is now the border between southern and northern subareas of forest-steppe. Calcium carbonate has been found in buried soils, which suggests that there was 
a lack of humidity when they were formed. At Chekalino IV, the layer with an Early Neolithic complex dated by shells to 8000-7900 BP yielded spore/pollen test results which indicated grassy and suffruticose vegetation comprising wormwood and chenopodiacious plants (68\%). About $15 \%$ are woody and covered the river valley. Thus this natural environment is rather similar to the picture reconstructed from the materials from the southern part of Middle Povolzhye. In other words, steppe landscapes of southern type spread up to the basin of the River Sok. Saiga bones found in the cultural layers of the Chekalino IV and Lebyazhinka IV sites (Mamonov 2006.94) offer further support this conclusion. Perhaps the appearance of Early Neolithic sites in this period was the result of aridisation at the end of the Boreal $c .8200 \mathrm{BP}$, although we should be careful with this supposition (Budja 2007.191-201).

The second group of Early Neolithic sites in the Middle Povolzhye forest-steppe is presented by materials from Staro-Elshanskaya II on the River Samara (Fig. 3), Ilyinskaya on the River Sok (Fig. 4), and Ozimyenka II on the River Moksha (Fig. 5). The organic temper in the ceramics date the sites to the beginning of the $5^{\text {th }}$ millennium BP (Vybornov 2008). The ceramic technology is identical at both groups of sites. El- shanka pots were made of muddy clay, sometimes with chamotte temper (Vasilieva 2006), unlike Early Neolithic vessels from the northern Caspian region and northern Black Sea region cultures, which were made of silts with bivalve shell impurities. The tradition of chamotte temper is typical of the Neolithic cultures of the Central Asian interfluve and eastern Caspian Sea region (Tsetlin 2007.205-206). There is similarity in the shapes of vessels (profiled, biconical, pointed bottom) and elements of ornament (Vinogradov 1968.85, 108; Vinogradov, Mamedov 1975. 88, 94, 110, 136, 157, 194, 203; Vinogradov 1981. $69)$. These pottery types have been dated to the end of the $6^{\text {th }}$ millennium BP (Vinogradov 1981.132). This date is confirmed at Ayakagytma site in the SubAral area by six ${ }^{14} \mathrm{C}$ dates ranging from $7190 \pm 20 \mathrm{BP}$ to $7030 \pm 90$ BP (Szymczak 2006.26). Sudden aridisation in $7200 \mathrm{BP}$ east of the northern Caspian Sea region has been detected, which compelled people to migrate north (Spiridonova, Aleshinskaya 1999. 25). This dynamic seems possible, as data showing that the Amu Darya fell into not the Aral but the Caspian Sea (Timofeev et al. 2004.19). The arrowheads found here show that some Central Asian groups of the Kelteminarskaya culture migrated here (Doubyagin et al. 1982.122). These arrowheads are also found in northern regions as far as the Middle Povol-

\begin{tabular}{|c|c|c|c|c|}
\hline No. Site & Lab. No. & Material & $\begin{array}{l}\text { Uncalibrated date } \\
\text { (BP) }\end{array}$ & $\begin{array}{l}\text { Calibrated date } \\
\text { one sigma (BC) }\end{array}$ \\
\hline 1. Kairshak III & Ki 16401 & shells from pottery & $7870 \pm 100$ & $7050-6500$ \\
\hline $\begin{array}{ll}\text { 2. } & \text { Kairshak III } \\
\end{array}$ & Ki 16400 & pottery carbon & $7290 \pm 190$ & $6500-5700$ \\
\hline 3. Tenteksor I & Ua 35266 & shells from pottery & $7235 \pm 45$ & $6250-5890$ \\
\hline 4. $\quad$ Tenteksor I & Ua 35267 & pottery carbon & $6695 \pm 40$ & $5730-5480$ \\
\hline $\begin{array}{ll}5 . & \text { Ivanovskaya }\end{array}$ & Ki 14568 & pottery carbon & $7930 \pm 90$ & $7080-6590$ \\
\hline $\begin{array}{ll}6 . & \text { Ivanovskaya }\end{array}$ & Le 2343 & bone & $8020 \pm 90$ & $7038-6718$ \\
\hline 7. $\quad$ Old Elshanskay-II & Ki 14413 & pottery carbon & $6820 \pm 80$ & $5880-5610$ \\
\hline 8. $\quad$ Iliinskaya & Le 5839 & shells & $8510 \pm 60$ & $7610-7450$ \\
\hline 9. Iliinskaya & Ki 14096 & pottery carbon & $6940 \pm 90$ & $5930-5660$ \\
\hline 10. Ozimenki-II & Ki 12168 & pottery carbon & $6950 \pm 170$ & $6250-5500$ \\
\hline 11. Chekalino IV & Le 4781 & shells & $8990 \pm 100$ & $8080-7935$ \\
\hline 12. Chekalino IV & Gin 7085 & shells & $8680 \pm 120$ & $7890-7570$ \\
\hline 13. Chekalino IV & Ki 14704 & soil & $6070 \pm 90$ & $5300-4700$ \\
\hline 14. Chekalino IV & Ki 14705 & pottery carbon & $5910 \pm 90$ & $5000-4540$ \\
\hline 15. Chekalino IV & Ki 14687 & soil & $6030 \pm 100$ & $5300-4650$ \\
\hline 16. Chekalino IV & Ki 14686 & pottery carbon & $5910 \pm 90$ & $5000-4540$ \\
\hline 17. Chekalino IV & Ki 14706 & shells & $6180 \pm 90$ & $5320-4900$ \\
\hline 18. Chekalino IV & Ki 14689 & shells & $6100 \pm 140$ & $5400-4650$ \\
\hline 19. Lebyazhinka IV & Gin 7088 & shells & $8470 \pm 140$ & $7590-7400$ \\
\hline 20. Lebyazhinka IV & Ki 14076 & pottery carbon & $6680 \pm 80$ & $5740-5470$ \\
\hline 21. Lebyazhinka IV & Ki 16852 & pottery carbon & $5950 \pm 70$ & $5040-4680$ \\
\hline 22. Vyunovo Lake & Le 9219 & soil & $5790 \pm 130$ & $4950-4350$ \\
\hline 23. Nizhnaya Orlyanka & Ki14123 & pottery carbon & $5720 \pm 80$ & $4730-4360$ \\
\hline
\end{tabular}

Tab. $1 .{ }^{14} \mathrm{C}$ dates of the Neolithic sites in the Povolzhye forest-steppe. 
zhye forest-steppe (Vinogradov 1979.5). Typical Central Asia geometric microliths and trapezes have been discovered in the same region in Neolithic complexes (Vybornov, Penin 1979.5; Morgunova 1980. 119). I suggest the most probable migration route was from the northern Caspian Sea to the head of the River Ural, where the latter meets the River Samara. The Chernikov brod I site located in this area is believed to be evidence of this route. Pottery with straight walls, pointed bottom, and lacking ornamentation has been discovered here which, on the other hand, is believed to refer to Elshanka culture (Mos$\sin 2007.79$ ).

Elshanka pottery was discovered at the Chekalino IV (Fig. 6), Nizhnyaya Orlyanka II (Fig. 7), and Lebyazhinka IV (Fig. 8) sites on the River Sok, and at Vyunovo Lake on the River Soura. Excavations at Chekalino IV in 2007 (Vybornov et al. 2009) provided new ${ }^{14} \mathrm{C}$ dates of $6070 \pm 90 \mathrm{BP}(\mathrm{Ki}-14704)$ and $6030 \pm$

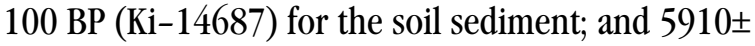
$90 \mathrm{BP}(\mathrm{Ki}-14705)$ and $5910 \pm 90$ (Ki-14686) BP for pottery carbon; and $6100 \pm 140 \mathrm{BP}(\mathrm{Ki}-14689)$ and $6180 \pm 90 \mathrm{BP}$ (Ki-14706) for shells. The pottery carbon dates at the Nizhnaya Orlyanka site are $5720 \pm$ $80 \mathrm{BP}$ (Ki-14123) and at Lebyazhinka IV 5970 \pm 70 BP (Ki-16852), respectively. The soil sediment dates from the Elshanka Vyunovo lake dwelling site date to $5790 \pm 130 \mathrm{BP}$ (Le-9219). The materialities and the radiocarbon dates from the sites correspond well with those at the Dzhebel site in the eastern Caspian Sea Region (Okladnikov 1956), which is dated to $6140 \pm 80 \mathrm{BP}$ (P-3081) and 6030 $240 \mathrm{BP}$ (Le-1).

It should be noted that only wild animal bones were found at the sites where Elshanka pottery was discovered. Therefore, I suggest not connecting the Neolithisation of the Povolzhye forest-steppe with a productive economy.

Thus the non-linear nature of the development of Early Neolithic culture in the Middle Povolzhye is clear. This conclusion is supported by processes discovered in other cultures (Budja 2006.183-201).

\section{ACKNOWLEDGEMENTS}

The author is grateful to Professor M. Budja for his invitation to the Seminar in November 2010, to the ARRS of Slovenia for hospitality, RGNF for support with grant 10-01-00393, to G. I. Zaytseva, N. N. Kovaliukh and $V$. V. Skripkin for ${ }^{14} C$ dating, to A. Papsheva for the translation of this paper.

\section{REFERENCES}

BALOSSI F. R. 2006. Development of 'Cultural Regions' in the Neolithic of the Near East. BAR International Series 1482. Archaeopress, Oxford.

BUDJA M. 2006. The transition to farming and the ceramic trajectories in Western Eurasia: from ceramic figurines to vessels. In M. Budja (ed.), $13^{\text {th }}$ Neolithic Studies. Documenta Praehistorica 33: 183-201.

2007. The $8200 \mathrm{cal}$ BP climate event and the process of neolithisathion in south-eastern Europe. In M. Budja (ed.), 14th Neolithic Studies. Documenta Praehistorica 34: 191-201.

DANILENKO V. N. 1969. Neolit Ukrainy (Neolithic of the Ukraine). Kiev (in Russian).

DOLUHANOV P. M. 2003. Neolitizatsiya Evropy: hronologiya i modeli (Neolithisation of Europe: chronology and models). Neolit i jeneolit juga i neolit severa Vostochnoj Evropy. S-Peterburg: 200-204 (in Russian).
DUBYAGIN P. S. CHIKRIZOV F. D., CHURINOV V. A., VASILIEV I. B. and VYBORNOV A. A. 1982. Novye materialy neolita-eneolita iz Severnogo Prikaspiya (The new materials in Neolithic-Eneolithic in the south Caspian Sea region). In N. Merpert (ed.), Volgo-Uralskaya step i lesostep v epohu rannego metalla. Kuybyshev: 92-134 (in Russian).

GRONENBORN D. 2009. Climate fluctuations and trajectories to complexity in the Neolithic: towards a theory. In M. Budja (ed), 16 th Neolithic Studies. Documenta Praehistorica 36: 97-110.

KOTOVA N. S. 2002. Neolitizatsiya Ukrainy (The Neolithisation of Ukraine). Lugansk (in Ukrainian).

KOZLOWSKI S. K., AURENCHE 0. 2005. Territories, Boundaries and Cultures in the Neolithic Near East. BAR International Series 1362. Archaeopress, Oxford.

LASTOVSKIY A. A. 2006. 0 kulturnom statuse keramiki elshanskogo tipa (Cultural status of Elshanka type pottery). Voprosy arheologii Povolzhya 4: 107-112 (in Russian). 
MAMONOV A. E. 1999. O kulturnom statuse elshanskih kompleksov (Cultural status of Elshanka complexes). Voprosy arheologii Povolzhya 1: 15-43 (in Russian).

2000. Elshanskaya kultura (Elshanka Culture). Istoriya Samarskogo Povolzhya s drevneyshih vremen do nashih dney. Samara (in Russian).

2006. Prirodnaja sreda v rannem neolite Samarskogo Zavolzhya i Orenburgskogo Priuralya i adaptacionnyj aspekt izucheniya elshanskoy kultury (The natural environment in Early Neolithic in Samara, Zavolzhye and Orenburg, Pre-Urals and the adaptation of Elshanka culture). Arheologicheskoe izuchenie centralnoy Rossii. Lipetsk: 93-95 (in Russian).

2006a. Elshanskaja kultura: problemy izucheniya i hronologicheskiy aspect (Elshanka Culture: research problems and chronological aspect). Aktualnye problemy istorii, arheologii, etnografii. Samara: 269-276 (in Russian).

MORGUNOVA N. L. 1980. Ivanovskaya stoyanka epohi neolita-eneolita v Orenbourgskoy oblasti (The NeolithicEneolithic Ivanovskaya site in Orenburg Oblast). Eneolit Vostochnoy Evropy. Kuybyshev: 104-124 (in Russian).

1995. Neolit $i$ eneolit yuga lesostepi Volgo-Uralskogo mezhdurechya (The Neolithic and Eneolithic in the south Volga-Ural interfluves forest-steppe). Orenbourg (in Russian).

MOSSIN V. S. 2007. Yug Urala v neo-eneoliticheskoe vremya (The Neo-Eneolithic period in southern Urals. In N. Morgunova (ed.), Arheologicheskie pamyatniki Orenburzhya. Orenburg: 76-81 (in Russian).

NIKITIN V. V. 2006. Obshchie cherty i specificheskie elementy ranneneoliticheskoy posudy lesnogo Povolzhya, stepnyh i lesostepnyh rayonov Volgo-Donskogo mezhdurechya (Early Neolithic pottery in Povolzhye forest and in desert and forest-steppe in Volga-Don interfluves regions). Arheologicheskoe izuchenie Centralnoy Rossii. Lipetsk: 97-102 (in Russian).

NISHIAKI Y., LE MIERE M. 2005. The oldest pottery Neolithic of upper Mesopotamia. Paleorient 31(2): 55-68.

OKLADNIKOV A. P. 1956. Peshchera Dzhebel - pamyatnik drevney istorii kultury prikaspiyskih plemen Yuzhnoy Turkmenii (Dzhebel Cave - monument of the ancient culture of South Turkmenian tribes in Caspian Sea region). Trudy YuTAKYe 2. Ashkhabad (in Russian).

STAVICKIY V. V. 2005. Problema neolitizatsii Volgo-Donskoy lesostepi (Problem of the Volga-Don forest-steppe neolithisation). Novye gumanitarnye issledovaniya. Samara: 145-151 (in Russian).
SPIRIDONOVA E. A., ALESHINSKAYA A. S. 1999. Periodizatsiya neolita-eneolita Evropeyskoy Rossii po dannym palinologicheskogo analiza (The Neolithic-Eneolithic periodization of European Russia according to the palynological data). Rossiyskaya arheologiya 1: 23-33 (in Russian).

SZYMCZAK K. KHUDZHANAZAROV M., FONTUGNE M. et al. 2006. Exploring the Neolithic of the Kyzyl-Kums. Central Asia-prehistoric studies 2 Institute of Archaeology, Warsaw University. Warsaw.

TIMOFEEV V. I. 2002. Nekotorye problemy neolitizatsii Vostochnoy Evropy (Some problems of neolithisation of Eastern Europe). Tverskoy arheologicheskiy sbornik 5: 209-215 (in Russian).

TIMOFEEV V. I., ZAYCEVA G. I., DOLUHANOV P. M. and SHUKUROV A. M. 2004. Radiouglerodnaya khronologiya neolita Severnoy Evrazii (Radiocarbon chronology of the Neolithic jn Northern Eurasia). Tesa. St. Petersburg (in Russian).

TSETLIN J. B. 2007. O proishozhdenyi verhnevolzhskoj kultury. Vliyanie prirodnoy sredy na razvitie drevnih soobshestv (The origin of Upper-Volga River culture. The influence of natural environment on prehistoric communities). In V. Nikitin (ed.), Materiali nauchnoi konferencii (The materials of scientific conference), Yoshkar0la: 197-208 (in Russian).

VASILIEV I. B., PENIN G. G. 1977. Elshanskie stoyanki na r. Samare v Orenburgskoy oblasti (Elshanka sites on the River Samara in Orenbourg Region). Neolit i bronzoviy vek Povolzhya $i$ Priuralya (Povolzhye and Priuralye Neolithic and Bronze Age). Kuybyshev: 3-22 (in Russian).

VASILIEV I. B. and VYBORNOV A. A. 1988. Neolit Povolzhya (Povolzhye Neolithic). Kujbyshev (in Russian).

VASILIEVA I. N. 2006. K voprosu o zarozhdenii goncharstva v Povolzhye (The pottery origin in Povolzhye). Voprosy arheologii Povolzhya 4: 426-439.

VINOGRADOV A. V. 1968. Neoliticheskie pamjatniki Horezma (Neolithic monuments in Khorezm). Moscow (in Russian).

1979. 0 rasprostranenii nakonechnikov strel kelteminarskogo tipa (Spread of Kelteminarskiy point type). Etnografiya $i$ arheologiya Sredney Azii. Moscow: 3-10 (in Russian).

1981. Drevnye ohotniki i rybolovy Sredneaziatskogo mezhdurechya (Hhunters and fishermen in Central Asian interfluve prehistory). Moscow (in Russian). 
VINOGRADOV A. V. and MAMEDOV E. D. 1975. Pervobytniy Lyavlyakan (Autochthonous Lyavlyakan). Moscow (in Russian).

VISKALIN A. V. 2002. Puti neolitizatsii Volgo-Kamya (k postanovke voprosa) (The neolithisation in Volga-Kama region). Tverskoy arheologicheskiy sbornik 5: 274-281 (in Russian).

2006. K voprosu o datirovke ranneneoliticheskoy keramiki elshanskogo tipa (The Early Neolithic Elshanka type pottery dating). Tverskoy arheologicheskiy sbornik 6: 260-265 (in Russian).

2009. Kulturno-hronologicheskye gruppy rannego neolita Volgo-Uralskoy lesostepi (Early Neolithic cultural and chronological groups in Volga-Ural forest-steppe). Tverskoy arheologicheskiy sbornik 7: 159-169 (in Russian).
VYBORNOV A. A. 2008. Neolit Volgo-Kamya (The Neolithic in Volga-Kama Region). Samara (in Russian).

VYBORNOV A. A., PENIN G. G. 1979. Neoliticheskye stoyanki na reke Samare (Neolithic sites on the River Samara). Drevnyaya istoriya Povolzhya (The prehistory of Povolzhye). Kuybyshev: 3-14 (in Russian).

VYBORNOV A., DOLUKHANOV P., ALEKSANDROVSKY A., KOVALIUKH N., SKRIPKIN V., SAPELKO T., ZAYTSEVA G. and SHUKUROV A. 2009. The Middle Volga Neolithic. In P. M. Dolukhanov (ed.), The East European Plain on of Eve of Agriculture. BAR International Series 1964. Archaeopress, Oxford: 71-80.

ZAYTSEVA G., SKRIPKIN V., KOVALIUKH N., POSSNERT G., DOLUKHANOV P. and VYBORNOV A. 2009. Radiocarbon dating of Neolithic pottery. Radiocarbon 51(2): 795801 . 


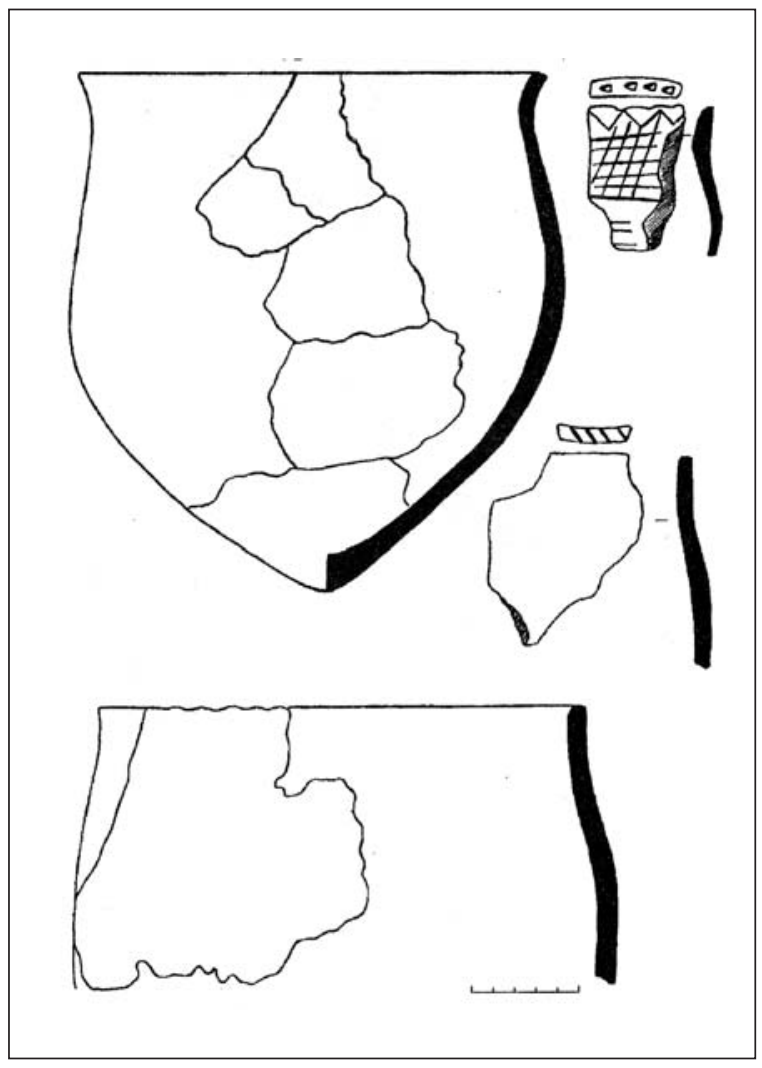

Fig. 2. Elshanian pottery. Ivanovskaya site.

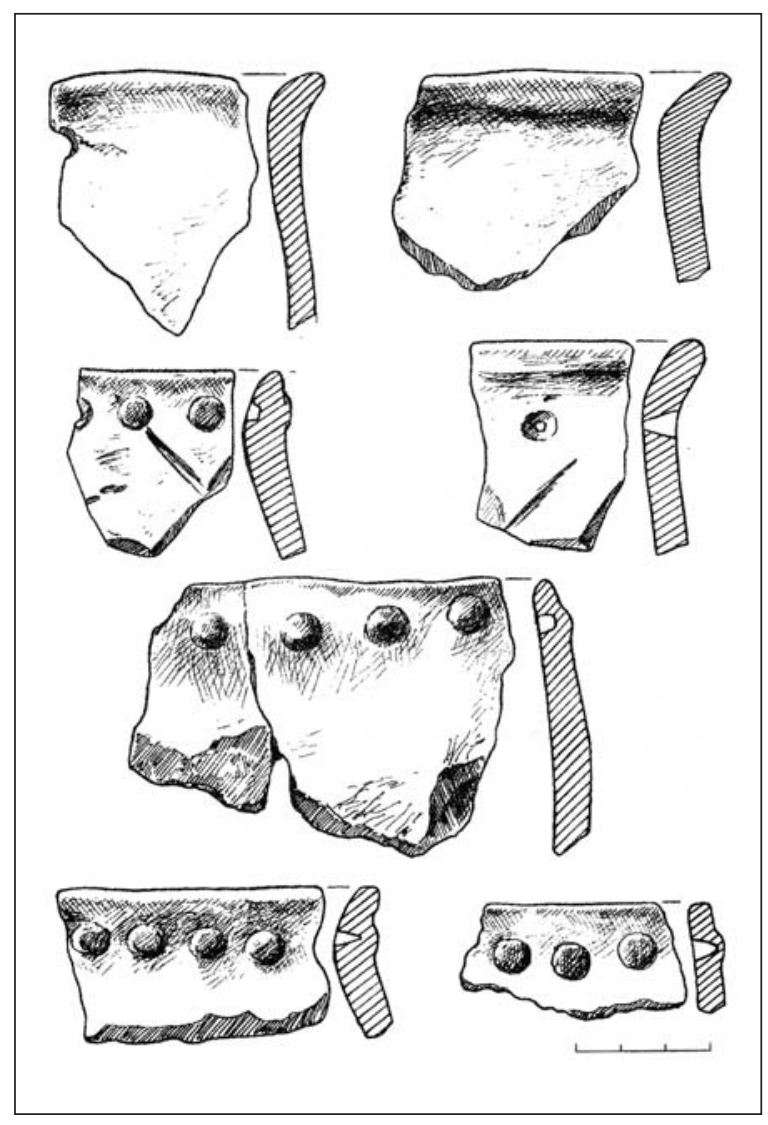

Fig. 4. Elshanian pottery. Iliinskaya site.

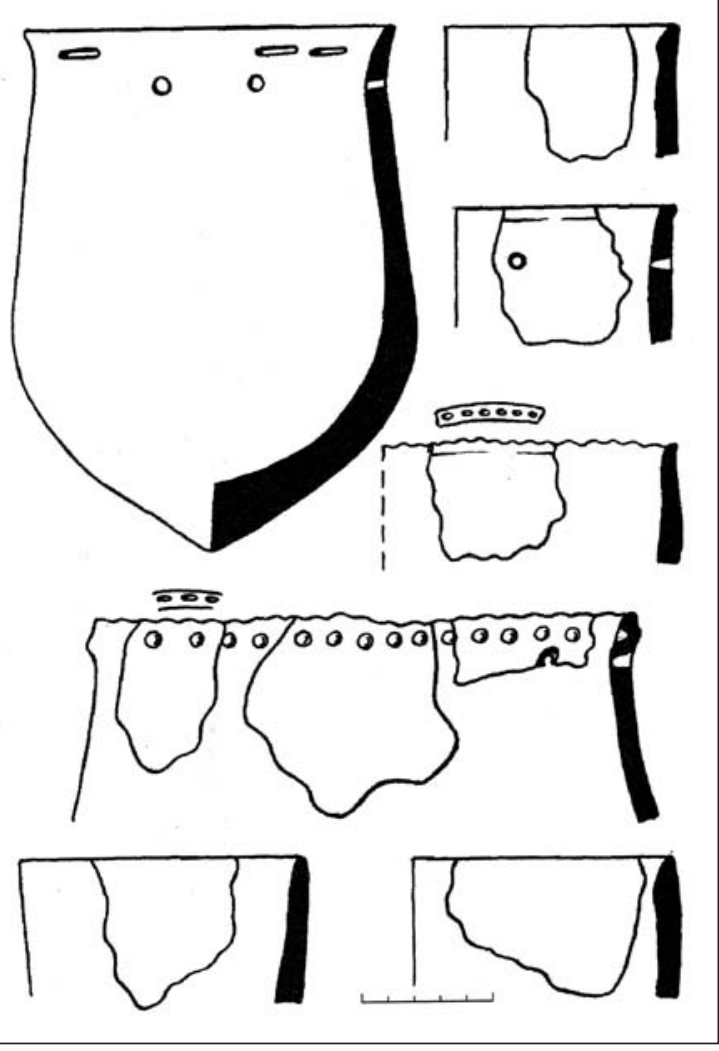

Fig. 3. Elshanian pottery. II Staro-Elshanskaya site.

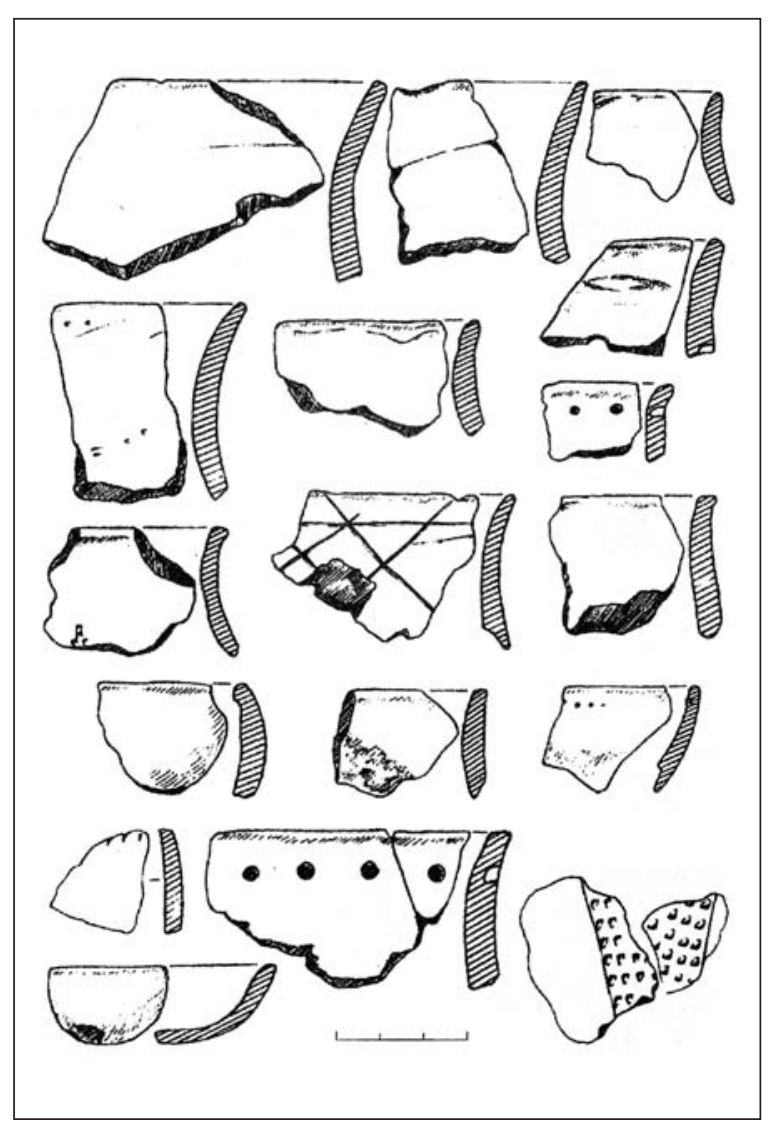

Fig. 5. Elshanian pottery. Ozimyenka II site. 


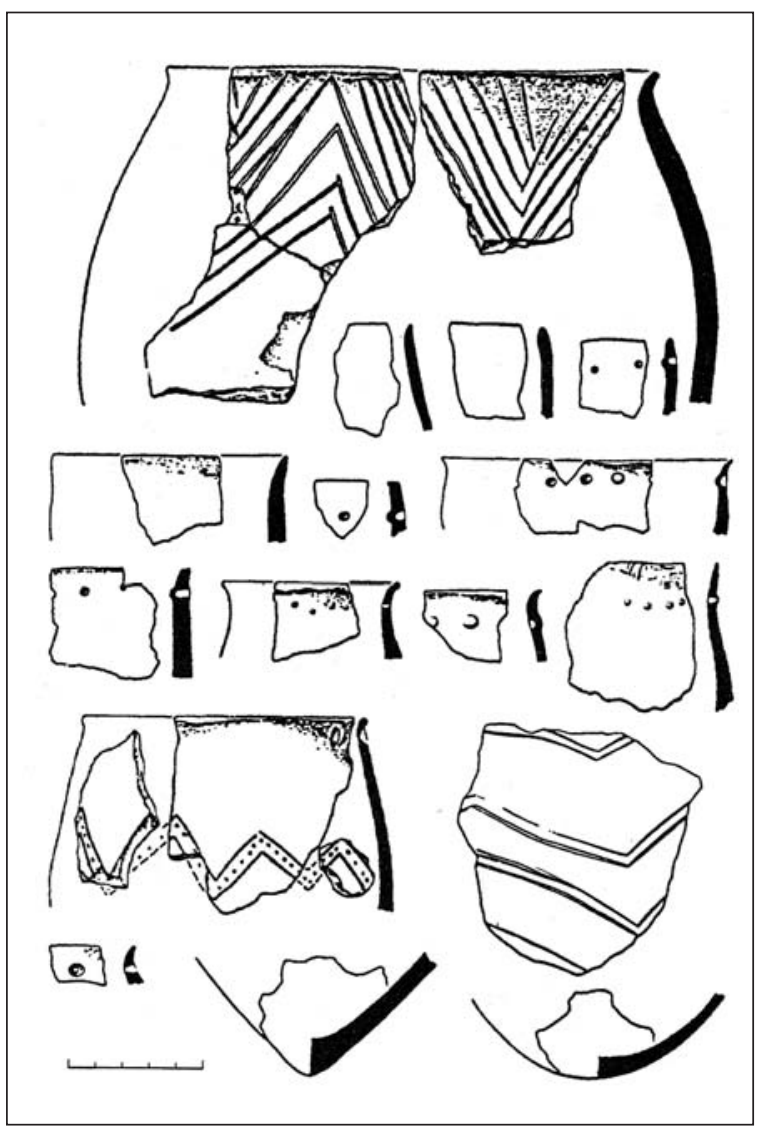

Fig. 6. Elshanian pottery. Chekalino IV site.

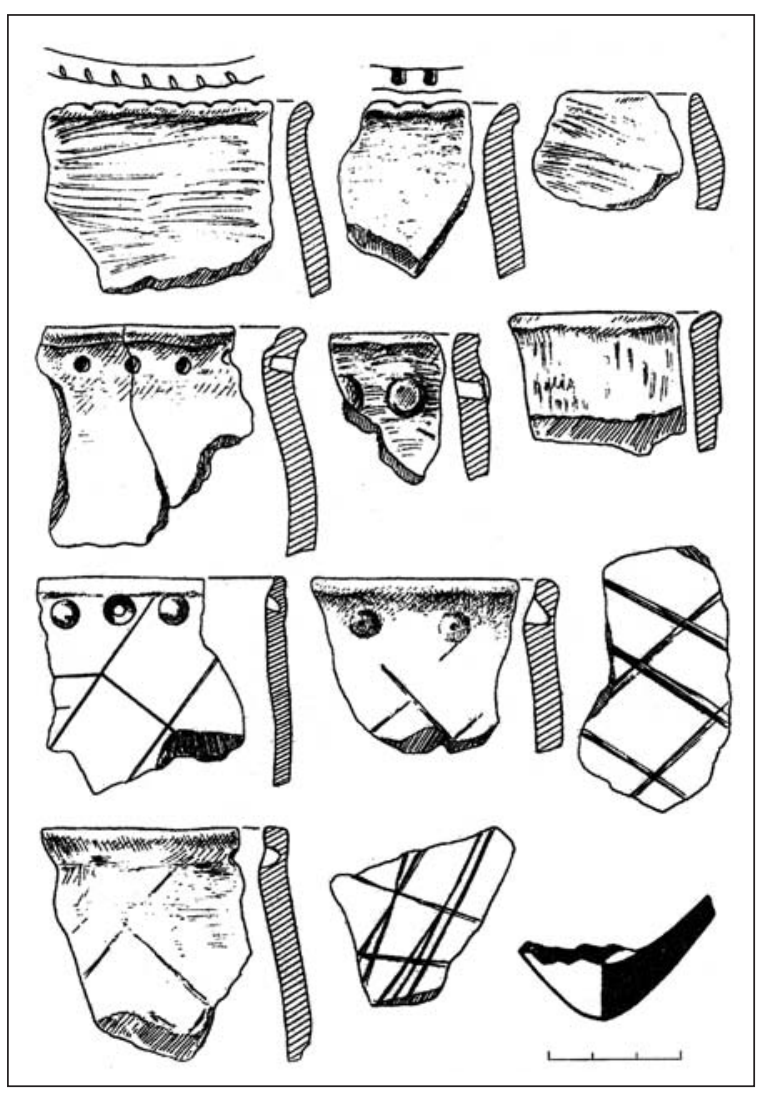

Fig. 8. Elshanian pottery. Lebyazhinka IV site.

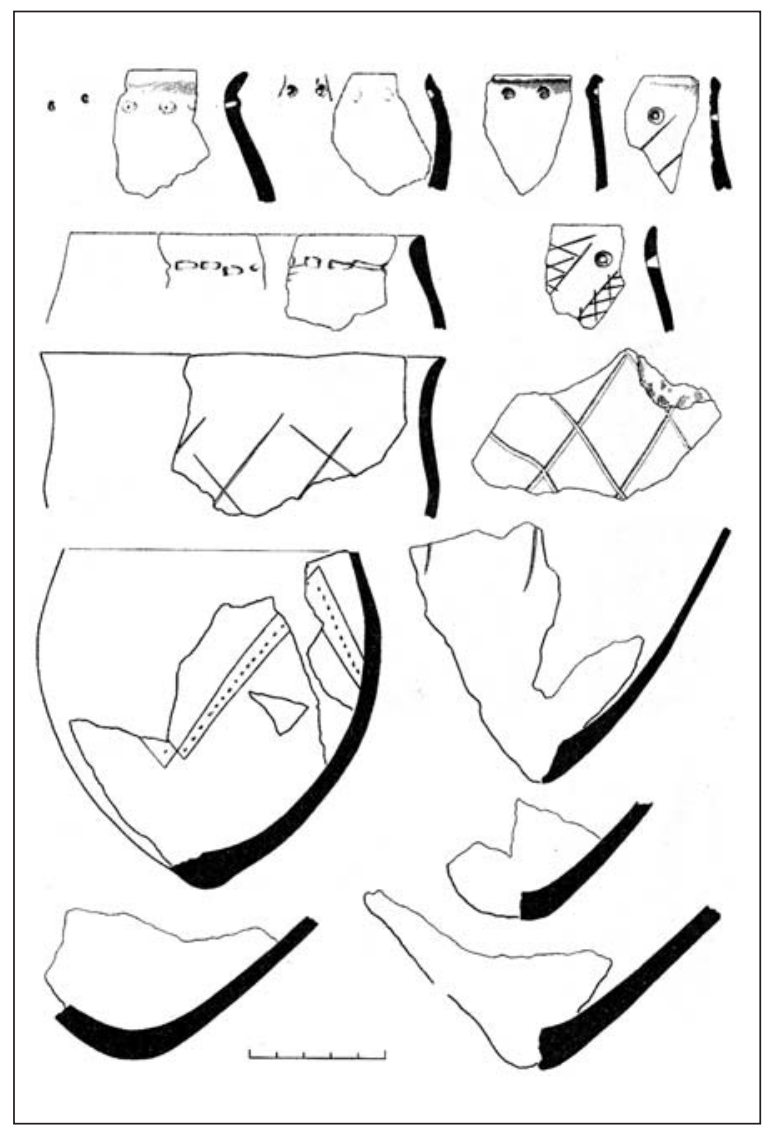

Fig. 7. Elshanian pottery.Nizhnyaya Orlyanka II site. 